(Житомирський державний університет імені Івана Франка) liliya meleshko@ukr.net ORCID: $00 \overline{0} 0-0003-0480-5693$

\title{
КОНЦЕПЦІЇ МОВНОЇ ГРИ ЯК ТЕОРЕТИЧНІ ЗАСАДИ ОРГАНІЗАЦІЇ НАВЧАЛЬНО-ІГРОВОЇ ДІЯЛЬНОСТІ
}

У статті розглянуто лінгвофілософські й лінгвістичні концепиії мовної гри як підгрунтя організації навчально-ігрової діяльності в системі українськомовної освіти. На основі наукового осмислення окреслено зміст понять "гра", "навчально-ігрова діяльність", "мовна гра". Шляхом аналізу наукової літератури й синтезу теоретичних ідей визначено принщипи побудови й реалізаиії навчальнометодичної системи, спрямованої на формування мовної особистості школяра в навчально-ігровій діяльності.

Ключові слова: гра, навчально-ігрова діяльність, мовна гра, методика ігрового навчання мови.

Постановка проблеми. У сучасних умовах розвитку шкільної українськомовної освіти одним із актуальних завдань постає формування в учнів готовності до ефективної комунікативної діяльності в різних сферах соціокультурного життя. Значний потенціал для розв'язання цього проблемного завдання мають варіативні методики, розроблені з використанням інтерактивних методів навчання. Серед інтерактивних методів особливу цінність має навчальна гра. Ігровий метод $є$ важливим для когнітивно-комунікативної підготовки зростаючої мовної особистості. У лінгводидактичній проекції проблема використання гри з метою формування мовнокомунікативної компетентності учнів тісно пов'язана з науковим завданням розкрити лінгвістичні засади навчально-ігрової діяльності й розробити на їх основі відповідну навчально-методичну систему.

Аналіз останніх досліджень і публікацій. Вивчення наукових праць, присвячених розв'язанню проблеми ігрової діяльності в навчанні мови, свідчить, що в роботах учених-лінгводидактиків (А. Богуш, О. Горошкіної, С. Карамана, П. Копосова, М. Пентилюк та ін.) розкрито деякі питання щодо організації навчально-ігрової діяльності в процесі опанування шкільного курсу української мови. Зокрема, О. Кучерук зазначає, що розвиток мовленнєвої креативності потребує певної системи навчальних дій: від стимулювання вчителем в учня мовної гри (гри слів - добір слів, близьких за звучанням; створення загадок на основі відсікання, додавання, переставляння букв чи складів у певному слові; складання каламбурів за поданими моделями, словами тощо) до прояву усвідомленого бажання самостійної мовленнсвої творчості [1: 83]. Інтерес сучасних дидактиків-філологів до окремих аспектів організації ігрової діяльності учнів у навчанні мови можна пояснити тим, що гра дає змогу створити розвивальне навчальне середовище, підвищити мотивацію учнів до навчання мови та поліпшити якісні показники навчально-предметних досягнень учнів. Аналіз наукових джерел переконує, що створення й обгрунтування ігрових методик навчання української мови - проблема, яка залишається актуальною й потребує значної науково-методичної роботи.

Мета статті - розглянути лінгвофілософські й лінгвістичні концепції мовної гри як основу організації навчально-ігрової діяльності в системі мовної освіти. Серед завдань виділяємо такі: окреслити взаємозв'язок між поняттями гра, мовна гра, навчально-ігрова діяльність; визначити наукові положення, які становлять лінгвістичні засади навчально-ігрової діяльності в системі українськомовної освіти; сформулювати лінгводидактичні умови реалізації такої діяльності.

Виклад основного матеріалу. Теоретичне переосмислення засад сучасної шкільної українськомовної освіти потребує якісного вдосконалення методики на ідеях інтерактивного навчання мови, зокрема створення ігрових ситуацій і технологій. Для цього важливо чітко розуміти взаємозв'язок понять гра, мовна гра, навчально-ігрова діяльність та належно оперувати ними у площині мовно-освітньої практики.

Г.-Г. Гадамер стверджує, що гра - це елементарна функція людського життя, отож людська культура без елементу гри взагалі немислима. Філософ серед визначальних ознак гри наводить такі: 1) ритмічний рух, який незмінно повторюється й не пов'язаний 3 певною метою; 2) гра як саморух, який не має осмисленої мети; 3) гра - дія без мети, дія як така; 4) особливість людської гри полягає в тому, що гра спроможна залучати в себе розум, цю здатність людини ставити перед собою мету й свідомо прагнути до неї та водночас спроможна й приборкати це прагнення ставити перед собою мету; власне людяністю людської гри $є$ те, що в ній ігрові рухи, так би мовити, самі себе дисциплінують і впорядковують, неначе в цьому справді мета; 5) гра завжди вимагає співучасті в ній; 6) гра є комунікативною дією, вона не знає дистанції між тим, хто грає, і тим, хто спостерігає за грою, у грі кожен завжди співучасник (це справедливо й для мистецької гри); 7) у грі проступає щось на кшталт герменевтичної ідентичності - розуміючи, ми ідентифікуємо щось із тим, що було чи є [2: 6975]. 
В "Енциклопедії освіти" (за редакцією В. Кременя) Н. Кудикіна зазначає, що гра - це вид креативної діяльності людини, у процесі якої в уявній формі відтворюються способи дій з предметами, стосунки між людьми, норми соціального життя та культурні надбання людства, які характеризують історично досягнутий рівень розвитку суспільства. Ігрова діяльність є складним системним утворенням, структура якого охоплює мотиваційно-цільовий, змістовий, процесуально-операційний, контрольно-оцінний та результативний компоненти [3: 139]. Тлумачення поняття "навчально-ігрова діяльність" потребує деякого уточнення. Навчально-ігрову діяльність пояснюємо як ігрову діяльність, спрямовану на досягнення навчальних цілей, iї результат характеризується особистісними змінами й навчальними досягненнями, оскільки вона пов'язана із засвоєнням знань, моделей комунікативної поведінки й виконанням різних навчально-предметних завдань.

Характерною ознакою навчально-ігрової діяльності в шкільному курсі української мови є мовна гра. Відповідно теоретичними засадами навчально-ігрової діяльності є лінгвофілософські й лінгвістичні концепції мовної гри.

Вважається, що поняття мовна гра в науковий обіг увів у XX столітті Л. Вітгенштейн. Зокрема, у праці "Коричнева книга" він 3 погляду лінгвофілософії називає мовними іграми такі системи комунікації, які відображають моделі наказу, запитання - відповіді, пояснення, опису, використання чисел у мовленні тощо. На його думку, мовні ігри схожі на те, що ми в повсякденній мові називаємо іграми [4: 235].

Сучасні мовознавці (Б. Норман, В. Санніков, Л. Цонева та ін.) вважають традиційне розуміння мовної гри лише як каламбуру (гри слів) обмеженим. Зокрема, Т. Космеда розглядає мовну гру як функціонально-стилістичне явище, що найповніше виявляється на рівні тексту (дискурсу), як усвідомлене відхилення від літературної норми, коли адресант навмисно порушує чинні норми 3 конкретною метою, розрахованою на те, що адресат має дешифрувати це відхилення. Дослідниця зазначає, що мовну гру не варто плутати із звичайною неграмотністю; щоб привернути увагу читачів (слухачів), необхідно зробити мову незвичною, позбавити іiї автоматизму. Для цього можна, наприклад, трансформувати відомі вислови, вжити оказіоналізми, поєднати різні стилі (наприклад офіційно-діловий і розмовний), обіграти внутрішню форму слова чи усталеного вислову, зіштовхнути різні граматичні форми і т. ін. Водночас дослідниця слушно застерігає, що залучати людину до мовної гри можна тільки після того, як вона оволодіє мовною нормою, нормативними засобами комунікації. Мовна гра - це усвідомлене порушення стереотипів. Її варто відрізняти від дитячої словотворчості [5: 139].

За Т. Біленко, "мовна гра припускає такі лексичні варіанти, які виявляють відмінності (специфіку) інтелектуального та культурного рівня суб'єкта, а також рівень соціальної (громадянської) відповідальності. У цьому полягає принципова відмінність мовної гри від гри загалом" [6: 98].

Отже, ураховуючи вищезазначене, мовну гру розглядаємо як функціонально-стилістичне явище, яке найповніше виявляється в тексті (дискурсі), це образний прийом, що виконує певну прагматичну функцію в мовленні. Щоб збагнути смисл мовної гри, особливо в образному тексті, потрібно знати й розуміти глибинні структури мови (текстів).

У сучасній науці поняття "мовна гра" - багатоаспектне. Мовну гру як спосіб актуалізації ключових ідей навчального курсу у викладанні лінгвістичних дисциплін досліджувала Т. Сурікова [7]. Цей підхід до мовної гри дає нам змогу виділити розгляд мовних ігор як способу актуалізаиії мови й основних ідей змісту відповідного їй навчального предмета як лінгводидактичну умову ігрової методики навчання.

У контексті лінгводидактичного дискурсу мовна гра виявляється, по-перше, у креативній мовленнєвій поведінці вчителя, учня; по-друге - у використанні образних дидактичних текстів, які потребують асоціативного мислення, лінгвокультурологічного знання для їх сприймання. Проблема мовної гри в лінгводидактичному розрізі стосується двох аспектів мовленнєвої діяльності: продукування мовної гри та сприймання гри як мовностильового прийому. Навчально-ігрова ситуація задає умови для мовної гри, а мовна гра становить спосіб комунікативної самореалізації, інтерпретації теми, навчального матеріалу. Мовні ігри на уроках мови можуть мати місце в актах читання, аудіювання, говоріння, письма. Ігрові моделі навчання української мови пов'язують, з одного боку, учня, дидактичний дискурс, учителя, а 3 іншого - автора, дидактичний текст, учня (учителя). Мовна гра в межах практичних навчальних ситуацій актуалізує творчі здібності мовця, приносить задоволення від вдало висловленої думки, радість відкриття оригінальної фрази, нових знань і смислів.

В методиці ігрового навчання мови мовна гра - компонент навчально-ігрової діяльності, специфіка цього компонента полягає в тому, що мовна гра поєднує в собі поняттєві ознаки ігрового використання мовних одиниць і спосіб активного навчання предмета. Оволодіти цим способом можна лише в процесі практичного застосування мовної гри 3 метою вираження навчально-виховних задумів тощо. Лінгводидактичною умовою ефективної реалізації ігрового підходу до організації шкільної українськомовної освіти $є$ дотримання таких принциипів: дидактичної метафоризації, культуровідповідності, природовідповідності, зв'язку структури моделі світу і поняттєвої структури мови, опори на креативність учня, опори на різні види мовленнєвої діяльності учня, ситуативності, методичної варіативності, діалогічності, рольової організації навчання, співпраці у навчанні тощо. 
Урахування виділених принципів у навчанні української мови дасть змогу забезпечити розвивальний характер навчальної діяльності учнів, спрямувати педагогічний процес на формування й підтримання високої внутрішньої мотивації до мовно-творчої діяльності, стимулювати мовленнсву креативність в ігровій діяльності під час розв'язання навчальних проблем.

Увага до мовної гри в методиці ігрового навчання мови дає змогу актуалізувати мовленнєвий досвід учня, прискорити його до дії - з одного боку, до естетичного сприйняття образного тексту, з іншого - до продукування власного оригінального мовлення в образно-виражальній формі. Окреслений підхід веде до засвоєння різних моделей мовомислення (метафоричні моделі, моделі каламбуру, римування, жарту, поєднання різних стилів мовлення та ін.), до вільного й оригінального самовираження учнів у дидактичному дискурсі.

Висновки. Отже, підвищення рівня мовної підготовки учнів значною мірою залежить від ігрового підходу до організації навчання. Поняття гра є загальним, родовим, щодо видів гри, зокрема таких як мовна гра та навчальна гра. Одна із сучасних технологій навчання мови - ігрова. Характерною ознакою навчально-ігрової діяльності в шкільному курсі української мови $є$ мовна гра, їі розглядаємо як функціонально-стилістичне явище, яке найповніше виявляється в тексті (дискурсі), це образний прийом, що виконує певну прагматичну функцію в мовленні.

Розроблення й упровадження ігрової лінгвометодичної системи визначається не лише психологопедагогічними чинниками, а й лінгвофілософськими і лінгвістичними, що забезпечують якість навчально-ігрової діяльності в процесі мовної освіти. Урахування в організації навчального курсу української мови лінгвофілософських і лінгвістичних положень щодо мовної гри (зокрема, гра $\epsilon$ комунікативною дією, мовну гру не варто плутати із звичайною неграмотністю, мовна гра - це усвідомлене порушення стереотипів та ін.) дає змогу реалізувати взаємозв'язок у розвитку загальних і навчально-предметних умінь, необхідних для сприймання образного дидактичного тексту й вільного та оригінального вираження особистих потреб, намірів засобами української мови. Успішність навчальноігрової діяльності на уроках мови залежить від дотримання лінгводидактичних умов, серед них принципів дидактичної метафоризації, опори на креативність учня, рольової організації навчання та ін. Перспективними $є$ дослідження методики формування в учнів індивідуальної мовної картини світу в процесі навчально-ігрової діяльності.

\section{СПИСОК ВИКОРИСТАНИХ ДЖЕРЕЛ ТА ЛІТЕРАТУРИ}

1. Кучерук О. А. Розвиток креативності мовної особистості учня основної школи / О. А. Кучерук // Вісник Житомирського державного університету імені Івана Франка. - 2013. - Вип. № 6 (72). - С. $82-87$.

2. Гадамер Ганс-Георг Герменевтика і поетика / Ганс-Георг Гадамер. - К. : Юніверс, 2001. - 288 с.

3. Енциклопедія освіти / Акад. пед. наук України; головний ред. В. Г. Кремень. - К. : Юрінком Інтер, 2008. $1040 \mathrm{c}$.

4. Витгенштейн Людвиг Избранные работы / Людвиг Витгенштейн ; пер. с нем. и англ. В. Руднева. - М. : Территория будущего, 2005. - $440 \mathrm{c}$.

5. Космеда Тетяна Мовна гра у системі лінгвістичних термінів / Тетяна Космеда // Культура слова. - 2011. № 74. - C. 137-141.

6. Біленко Тетяна Герменевтичні аспекти мовної гри (контекст екзистенції) / Тетяна Біленко // Людинознавчі студії. - 2013. - Випуск 28. Філософія. - С. 92-100.

7. Сурикова Т. И. Языковая игра как способ актуализации ключевых идей учебного курса в преподавании лингвистических дисциплин / Т. И. Сурикова // Игра как прием текстопорождения : [коллективная монографія] ; отв. ред. А. П. Сковородников. - Красноярск : Сибирский федеральный университет, 2010. C. $309-320$.

\section{REFERENCES (TRANSLATED \& TRANSLITERATED)}

1. Kucheruk O. A. Rozvytok kreatyvnosti movnoi osobystosti uchnia osnovnoi shkoly [The Developing Creativity of Linguistic Identity of Primary School Pupil] / O. A. Kucheruk // Visnyk Zhytomyrs'koho derzhavnoho yniversytetu imeni Ivana Franka [Zhytomyr Ivan Franko State University Journal]. - 2013. - Vyp. № 6 (72). - S. 82-87.

2. Gadamer Hans-Georg Hermenevtyka i poetyka [Hermeneutics and Poetics] / Hans-Georg Gadamer. - K. : Yunivers, 2001. $-288 \mathrm{~s}$

3. Entsyklopediia osvity [Encyclopedia of Education] / [Akad. ped. nauk Ukrainy; golovnyi red. V. G. Kremen'] - K. : Yurinkom Inter, 2008. - $1040 \mathrm{~s}$.

4. Vithenshtein Liudvih Izbrannyie raboty [Selected Works] / Liudvih Vithenshtein ; per. s nem. i anhl. V. Rudneva. M. : Territoriia budushcheho, 2005. $-440 \mathrm{~s}$.

5. Kosmeda Tetiana. Movna hra u systemi linhvistychnykh terminiv [Language game system of linguistic terms] / Tetiana Kosmeda // Kultura slova. - 2011. - № 74. - S. 137-141.

6. Bilenko Tetiana Hermevtychni aspekty movnoi hry (kontekst ekzystentsii) [Hermeneutic Aspects of Language Games (Context Existence)] / Tetiana Bilenko // Liudynoznavchi studii [Person Studing Studios]. - 2013. - Vyp. 28. - Filosofiia. - S. 92-100.

7. Surikova T. I. Yazykovaia ihra kak sposob aktualizatsii kliuchevykh idiei uchebnoho kursa v priepodavanii lingvistichieskikh ditsiplin [Language Game as a Way to Update the Key Ideas of the Training Course in Teaching 
Linguistic Disciplines] / T. I. Surikova // Ihra kak priiom tekstoporozhdieniia [Game as a Process of Textbirh] : [Kollektivnaia monohrafiia]; otv. red. A. P. Skovorodnikov. - Krasnoiarsk : Sibirskii fiedieralnyi univiersitiet, 2010. - S. 309-320.

\section{Мелешко Л. В. Концепции языковой игры как теоретические засады организации учебно-игровой деятельности.}

В статье рассмотрены лингвофилософские и лингвистические концепџии языковой игры, которые являют собой основу организации учебно-игровой деятельности в системе языкового образования. На базе научного осмысления определено содержание понятий "игра", "учебно-игровая деятельность" $и$

"языковая игра". Путем анализа научной литературы и синтеза теоретических идей намечень принципы построения и реализации учебно-методической системы, направленной на формирование языковой личности школьника в учебно-игровой деятельности на занятиях по украинскому языку.

Ключевые слова: игра, языковая игра, учебно-игровая деятельность, методика игрового обучения языку.

\section{Meleshko L. V. Concept of Language Game Theoretical Principles of Organization of Educational and Entertaining Activities.}

The theoretical reconsideration of the fundamentals of modern school Ukrainian-language education requires a qualitative improvement of the methodology on the ideas of interactive language learning, in particular, the creation of gaming situations and technologies. For this purpose, it is important to understand the interconnection of the concepts of the "game", "language game", "educational and game activities". Based on the analysis of the scientists' work, it was established that the game is a kind of creative activity of a person in the process of which, in an imaginary form, the ways of dealing with objects, relations between people, norms of social life and cultural heritage of mankind are reproduced.

Due to the synthesis of scientific provisions, educational-playing activities we can explain as the playing activities aimed at achieving educational goals, and its outcome is characterized by personal changes and academic achievements. It was found out that language play is a characteristic feature of educational-playing activity in the school course of the Ukrainian language. On the basis of generalization of the corresponding

linguophilosophical and linguistic concepts, we consider the language play as a functional-stylistic phenomenon, which is most fully reflected in the text (discourse), it is a figurative technique that performs a certain pragmatic function in speech. It was found that in the method of learning a language by playing, the language play is a component of educational-playing activity, the specifics of this component consists in the fact that the language play combines the conceptual features of the game use of the linguistic units and the method of active teaching of the subject. It is investigated that attention to the language game allows actualizing the student's speech experience, accelerating it to action - on the one hand, to aesthetic perception of figurative text, on the other hand - to the production of his own original speech in a figuratively-expressive form.

Taking into account the linguistic-philosophical and linguistic provisions concerning the language game, while organizing the Ukrainian language course, it is possible to realize the interconnection in the development of general and teaching-subject skills which are necessary for the perception of figurative didactic text and the free and original expression of personal needs, intentions by the means of Ukrainian language.

Key words: game, educational-gaming activity, language game, the method of game language training. 